\title{
AMPLIAÇÃO DO HOME OFFICE NA PANDEMIA DA COVID-19: TECNOLOGIA, MANUTENÇÃO DE ATIVIDADES EMPRESARIAIS E RESPEITO AO CONTRATO DE TRABALHO
}

\author{
Irineu Francisco Barreto Junior* \\ Luciana Guerra Fogarolli**
}

\begin{tabular}{l|l}
\hline RECEBIDO EM: & 8.11 .2021 \\
\hline APROVADO EM: & 3.12 .2021 \\
\hline
\end{tabular}

* Bacharel em Sociologia e Ciência Política pela Escola de Sociologia e Política de São Paulo, mestre em Ciências Sociais pela Pontifícia Universidade Católica de São Paulo (PUC-SP), doutor em Ciências Sociais pela PUC-SP e pós-doutor em Sociologia pela Universidade de São Paulo (USP). Docente do Programa de Mestrado em Direito da Sociedade da Informação e do curso de Graduação em Direito do Centro Universitário das Faculdades Metropolitanas Unidas (FMU-SP), do curso de Pós-Graduação em Direito Digital da Universidade Presbiteriana Mackenzie (UPM), da Escola Superior da Advocacia (ESA) da Ordem dos Advogados do Brasil (OAB-SP) e dos cursos de Pós-Graduação do Complexo de Ensino Renato Saraiva (Faculdade Cers). Membro do Conselho Nacional de Pesquisa e Pós-Graduação em Direito (Conpedi). Analista de pesquisas da Fundação Sistema Estadual de Análise de Dados (Seade-SP). Líder do Grupo de Pesquisa da Coordenação de Aperfeiçoamento de Pessoal de Nível Superior (Capes) Ética e Fundamentos Jurídico-Políticos na Sociedade da Informação. Ex-coordenador adjunto do curso de Graduação em Direito e da Comissão de Iniciação Científica da FMU. Membro do Conselho Editorial e Científico Nacional e Internacional da Revista Direitos Emergentes na Sociedade Global da Universidade Federal de Santa Maria(UFSM) e da Revista Eletrônica do Curso de Direito da UFSM.E-mail: irineu.jr@fmu.br

** Graduada em Direito pela Universidade do Estado da Bahia (Uneb), especialista em Direito e Processo do Trabalho pela Faculdade Baiana de Direito (FBD) e mestranda em Direito da Sociedade da Informação das Faculdades Metropolitanas Unidas (FMU).E-mail: lucianaguerra@duartegarcia.com.br 
- RESUMO: Este artigo analisa a importância do contrato de trabalho no regime home office, no contexto da pandemia decorrente da disseminação da Covid-19. Examina a disciplina legal desse modelo de contrato, identifica suas principais premissas e características, e analisa ainda as medidas provisórias e leis promulgadas no curso da pandemia que visaram viabilizar e desburocratizar a migração dos contratos de trabalho presenciais para esse modelo remoto. Adota-se o método dedutivo e realiza-se a revisão da doutrina, da jurisprudência, das pesquisas e das notas técnicas emitidas pelo Ministério Público do Trabalho sobre o tema apresentado. O estudo conclui que a tecnologia foi uma importante aliada para a manutenção de atividades econômicas em função da pandemia, mormente pelo uso do home office. A tecnologia permitiu a continuidade da prestação dos serviços respeitando o distanciamento social recomendado como medida de combate à disseminação do vírus. Palavras-chave: Home office; sociedade da informação; Covid-19.

\section{EXPANSION OF THE HOME OFFICE IN THE COVID-19} PANDEMIC: TECHNOLOGY, MAINTENANCE OF BUSINESS ACTIVITIES AND RESPECT FOR EMPLOYMENT CONTRACT

ABSTRACT: This paper proposes an analysis of the importance of the employment contract in the home office regime in the context of the pandemic resulting from the dissemination of the Covid-19 virus. The legal discipline of this contract model is examined, identifying its main premises and characteristics, also analyzing the provisional measures and laws enacted during the pandemic that aimed to facilitate and reduce bureaucracy the migration of in-person employment contracts to this model remote. The methodology used is based on deductive and inductive methods, reviewing the bibliography, seeking to visit the doctrine, jurisprudence, research, reports, technical notes issued by the Public Ministry of Labor and legislation on the topic presented. The study concludes that technology has been an important ally in preventing commercial activities due to the pandemic, especially using the home office, which allows the continuity of the provision of services respecting social distance, the latter recommended as a measure to combat spread of the virus.

- KeYwords: Home office; information society; Covid-19. 


\section{Introdução}

A pandemia decorrente da disseminação da coronavirus disease 2019 (Covid-19) trouxe impactos nos mais diversos setores da sociedade de maneira global, mormente nos segmentos da saúde e da economia, nas relações trabalhistas, na educação, entre outros. O vírus da Covid-19 foi detectado incialmente na China, disseminou-se, em pouco tempo, por todo o mundo e ganhou status de pandemia, demonstrando principalmente que, no estágio atual de globalização, os problemas que envolvem a saúde também atravessam fronteiras, ou seja, deixam de ser uma questão local e ganham proporções globais muito rapidamente.

Trata-se de um vírus novo que tem apresentado altas taxas de mortalidade pelo mundo. Só no Brasil, até 19 de junho de 2021, já se contabilizam mais de 500 mil mortos pelo vírus ("BRASIL ATINGE MARCA TRÁGICA DE 500 MIL MORTES PELA COVID”, 2021). O vírus é de fácil contágio, propagando-se pelo ar. Conforme já reconhecido pela própria Organização Mundial da Saúde (OMS), mesmo pessoas assintomáticas possuem o potencial de transmitir o vírus, o que dificulta a sua identificação $\mathrm{e}$ potencializa sua disseminação, sendo os principais meios de contágio via olhos, boca e nariz ("OMS ESCLARECE QUE ASSINTOMÁTICOS TRANSMITEM CORONAVÍRUS: 'A QUESTÃO É SABER QUANTO’”, 2020).

Por tratar-se de uma doença inédita e que vem apresentando diversas variantes pelo mundo, no início da pandemia, enquanto se iniciava uma verdadeira força-tarefa da ciência para criar uma vacina para combater a Covid-19, medidas comportamentais foram recomendadas pela OMS como forma de enfrentamento da disseminação do vírus, a exemplo do uso de máscaras, higienização das mãos com sabão ou álcool e, principalmente, o distanciamento social.

Atualmente, mesmo com a criação e a disponibilização da vacina, ao menos no Brasil, enquanto parte significativa da população ainda não é vacinada, essas recomendações ainda se mantêm.

Quanto ao distanciamento social, os impactos nas dinâmicas comercial, educacional, de saúde e laboral implicaram sensíveis transformações no país. O distanciamento social foi praticado principalmente pelas pessoas que possuem condições financeiras e que podem ficar em suas residências e evitar aglomerações em locais públicos ou privados, como ônibus, escolas, comércios, repartições, shopping centers etc.

Nesse contexto, a tecnologia emergiu mais do que nunca como uma ferramenta crucial para a não paralisação das atividades e estagnação país. Nas relações laborais, de 
especial interesse para o presente estudo, o modelo home office tem brilhado com protagonismo naqueles setores que não demandam necessariamente a presença física do trabalhador para o prosseguimento de suas atividades, seja no estabelecimento físico da empresa, seja na rua.

O modelo se apresentou, nesse contexto, como uma alternativa viável para a não paralisação dos negócios, permitindo a continuidade do trabalho prestado pela via remota, intermediada pela rede mundial de computadores interconectados via internet, no âmbito residencial dos trabalhadores.

No contexto pandêmico, pode-se afirmar que o home office se tornou até mesmo um instrumento de proteção à saúde do trabalhador e do próprio meio ambiente do trabalho, de responsabilidade do empregador na forma do inciso XXII do artigo $7^{\circ}$ da Constituição Federal, haja vista a impossibilidade de se prever o nível de gravidade, no trabalhador, quando eventualmente infectado pelo vírus.

Diante desse contexto, o presente artigo propõe um exame sobre a importância do contrato de trabalho no regime home office no contexto da pandemia decorrente da disseminação da Covid-19. Para tanto, o estudo é dividido em três unidades, sendo a primeira esta introdução. Na segunda seção, faz-se uma análise sobre o conceito do contrato de trabalho em regime home office, identificando suas principais características e requisitos formais, bem como peculiaridades e diferenças em torno do teletrabalho, trabalho remoto, trabalho externo e sua disciplina legal.

Na terceira unidade, é formulada uma contextualização do cenário da pandemia no Brasil, introduzindo-se o modelo home office como uma das principais ferramentas que tornam possível o distanciamento social e a continuação das atividades empresariais.

Além disso, são examinadas as medidas provisórias e leis promulgadas no país, no curso da pandemia, que visaram viabilizar e desburocratizar, mormente no âmbito das relações empregatícias, a migração dos contratos de trabalho presenciais para o modelo remoto, no regime de home office.

O estudo aponta que a tecnologia tem sido uma importante aliada para a não paralisação das atividades comerciais em função da pandemia, mormente pelo uso do home office, que permite a continuidade da prestação de serviços respeitando o distanciamento social. Neste estudo, adota-se o método dedutivo, e realiza-se a revisão da literatura, ao visitar a doutrina, acrescida de análise jurisprudencial, notas técnicas emitidas pelo Ministério Público do Trabalho e legislação que concerne ao tema apresentado. 


\section{Teletrabalho é gênero, e home office, espécie}

Antes de adentrarmos em conceitos e distinções do instituto home office, é importante situar esse modelo como um fruto típico da sociedade da informação atualmente vivida, caracterizada pela implementação da tecnologia e interconexão via internet de uma rede mundial de computadores com alcance global, marcada também pela geração e reprodução aplicada de dados que, transmitidos em tempo instantâneo, tornaram relativa até mesmo a noção estática de tempo e espaço no desenvolvimento das relações sociais. Barreto Junior (2007, p. 2), ao examinar o emergir da sociedade da informação no contexto da revolução digital, acrescenta o seguinte:

A sociedade contemporânea atravessa uma verdadeira revolução digital em que são dissolvidas as fronteiras entre telecomunicações, meios de comunicação de massa e informática. Convencionou-se nomear esse novo ciclo histórico de Sociedade da Informação, cuja principal marca é o surgimento de complexas redes profissionais e tecnológicas voltadas à produção e ao uso da informação, que alcançam ainda sua distribuição através do mercado, bem como as formas de utilização desse bem para gerar conhecimento e riqueza. Essa expressão tem sido utilizada com frequência cada vez maior em tempos contemporâneos, porém, o conceito advém da década de 60 , quando foi superado um estágio de desenvolvimento histórico e teve início um período marcado pela conformação de um novo paradigma de sociedade. Na sociedade contemporânea o novo modelo organizacional superaria a centralidade do controle e da otimização de processos industriais e alçaria o processamento e o manejo da informação para o centro das discussões no âmbito das ciências humanas e tecnológicas.

A sociedade da informação é instantânea e simultânea. Os meios telemáticos de comunicação permitem, por exemplo, em tempo real, que o indivíduo, a partir de um único local no mundo, reúna-se, comunique-se, interaja, execute serviços, mormente os de caráter intelectual, a qualquer hora, em qualquer lugar do mundo (e para qualquer lugar do mundo), bastando apenas ter disponível um computador ou dispositivo móvel e conexão com a internet.

Lisboa (2020, p. 27) aponta que a sociedade da informação é também caracterizada pela dependência da sociedade industrial da informação para melhora da competitividade de mercado, viabilizada pelo desenvolvimento tecnológico. Importante aqui se destacar que o marco da sociedade da informação hodiernamente vivida não 
se resume meramente à automação em si, pois as modificações geradas por esta, nas relações sociais, já foram experimentadas em outros momentos pela sociedade, como nas revoluções industriais anteriores.

A diferença característica desse momento peculiar e disruptivo é justamente a instantaneidade promovida pela tecnologia. Nesse contexto, a internet e a rede mundial de computadores interconectada assumem, sem dúvida, o protagonismo. Elas têm quebrado fronteiras físicas e temporais, e gerado circulação de dados, conhecimento e, muitas vezes, até desinformação, em velocidade nunca vista, além de criarem uma cultura própria e consolidarem de vez o fenômeno da globalização.

É justamente nesse contexto da sociedade da informação, impactada pela tecnologia de resultados instantâneos, independentemente de onde esteja o indivíduo, que emergem novas formas de trabalho até então nunca pensadas, quebrando muitas vezes critérios clássicos da estrutura organizacional firmados sobre o modelo em que, por exemplo, "O empregador mantém os meios de produção, e o empregado, a força de trabalho" ou “O empregado comparece às dependências da fábrica e responde a um chefe ou chefes, de maneira pessoal, estando sujeito a controle e fiscalização de jornada sob vigilância pessoal/presencial”. Rodrigues (2011, p. 25), sobre esse ponto, pontua com propriedade o seguinte:

A introdução da telemática na sociedade moderna trouxe importantes modificações relacionadas ao trabalho. Uma delas diz respeito ao modo de organização da empresa e da produção. Outra diz respeito ao tipo de trabalho e ao modo de desempenhá-lo, que envolve tanto os instrumentos utilizados quanto o local de trabalho.

As máquinas e instrumentos da telemática ocupam toda a organização empresarial e doméstica e, assim, causam uma desestruturação do modelo tradicional de tempo-espaço.

Nesse contexto, conforme dito alhures, é como um resultado do impacto da tecnologia das instantaneidades, na sociedade da informação, que emergem novas formas de trabalho, como o modelo home office e o teletrabalho de modo geral, tal qual também sinaliza Rodrigues (2011, p. 26):

A era industrial, caracterizada pela prestação de serviços no interior dos centros de produção, de grande e média dimensão, a tempo pleno, com a presença física do empregador ou de seus prepostos para fiscalizar, denominada pelos franceses de présenteisme, deu lugar à atual sociedade 
de informação. O trabalho a distância ganha novas proporções, nele incluído o trabalho em domicílio, com a fiscalização dos serviços sem a presença física do empregador e com preponderância da atividade intelectual sobre a ocupação manual. Neste contexto, a flexibilidade, aliada às modernas técnicas organizativas, com a utilização da telemática, afeta de maneira particular a gestão dos chamados recursos humanos e dá origem às novas formas de trabalho fundadas na polivalência, multifuncionalidade, na mobilidade profissional e geográfica e na criatividade

O Tribunal Superior do Trabalho - TST (2020), em cartilha publicada recentemente sobre o trabalho remoto, definiu, de forma muito simplificada, o "espírito" do que viria a ser o teletrabalho: "o trabalho de onde você estiver". Eé exatamente esse um ponto característico do instituto.

De antemão, é bom destacar que, apesar de eventuais confusões a respeito do assunto, teletrabalho, trabalho remoto e home office não são a mesma coisa. E como já adiantado desde o título desta seção, de maneira bem objetiva, o teletrabalho é gênero, enquanto o home office é uma das muitas espécies possíveis desse modelo.

De modo geral, o teletrabalho é o trabalho exercido preponderantemente fora das dependências da empresa, de maneira remota, com a utilização de recursos tecnológicos, intermediado pela rede mundial de computadores conectada via internet. Conforme define Rodrigues (2011, p. 28):

Podemos dizer que o teletrabalho origina da introdução das novas tecnologias da telemática no processo produtivo da empresa. O computador assume a posição de instrumento imprescindível de trabalho por grande parte dos profissionais modernos, sendo que, em alguns casos, a prestação de trabalho passa a ser executada exclusivamente através dos instrumentos da telemática, poderosas ferramentas de trabalho capazes de integrar economias locais e até mesmo globais. É o chamado mundo virtual ou ciberespaço.

Não se confunde, contudo, com o trabalho externo, como é o caso das atividades desempenhadas por motoristas e representantes. O principal traço característico do teletrabalho é o trabalho intermediado pela utilização de recursos tecnológicos e prestado na maior parte do tempo fora das dependências do empregador, não sendo o típico trabalho externo que, invariavelmente, demanda a presença física do trabalhador na consecução dos serviços, mesmo que fora da empresa. Na avaliação de Rodrigues (2011, p. 36): 
Assim, podemos dizer que o teletrabalho se caracteriza pelo desenvolvimento da atividade laborativa de forma telemática em um local distante da sede da empresa. O empregado se vale de uma estação de trabalho, operando através de uma base de dados ligada ao computador central localizado na empresa.

Um motorista de ônibus, por exemplo, desempenha suas atividades preponderantemente fora do estabelecimento da empresa. Todavia, não realiza nessa atividade o teletrabalho, pois essa não é realizada de maneira remota nem intermedida pelo uso de recursos tecnológicos. Demanda, inclusive, a presença física do trabalhador para que o veículo seja conduzido.

Portanto, o trabalho externo, como é no caso do exemplo citado, não é um tipo de teletrabalho. Dentro do instituto teletrabalho, também se identifica como uma de suas espécies o trabalho remoto. $\mathrm{O}$ trabalho remoto é aquele que pode ser prestado em lugares diversos da empresa, como uma cafeteria, uma lan house, telecentros, espaços de coworking, enfim, onde o trabalhador estiver.

Já o home office, como uma espécie também de teletrabalho, distingue-se dos demais modelos remotos por desenvolver-se necessariamente dentro do âmbito residencial do empregado e não em qualquer outro local. Barreto Junior e Silva (2015, p. 34) indicam ainda como espécies de teletrabalho domicílios centros satélites, telecentros, telecottages, nômade ou móvel.

Os autores estabelecem uma distinção entre o trabalho em domicílio (home office) do teletrabalho em geral quanto à limitação ao âmbito residencial deste último:

Esclarece Pinho Pedreira que "o trabalho a distância é gênero que compreende várias espécies, uma delas o teletrabalho (SILVA, 2000, p. 583)”. O trabalho a domicílio também é espécie desse gênero, mas não pode ser considerado como sinônimo de teletrabalho, uma vez que este, além do domicílio do teletrabalhador, pode ser exercido fora do estabelecimento patronal, em contato com ele, ou em outro local, de uso público ou não. A CLT em seu art. $6^{\circ}$ caput traz a figura do trabalho em domicílio, onde esclarece que que não se distingue entre o trabalho realizado no estabelecimento do empregador e o executado no domicílio do empregado. O teletrabalho, portanto, poderia ser associado com aquela modalidade de trabalho, pelo fato de ser igualmente prestado à distância (BARRETO JUNIOR; SILVA, 2015, p. 34). 
Em suma, home office é uma expressão específica para caracterizar o teletrabalho prestado em casa, abrangendo nessa categoria, inclusive, não somente empregados, mas também trabalhadores autônomos e freelancers. De tudo quanto exposto, é de se ver, portanto, que o teletrabalho é um termo mais abrangente, que comporta uma série de espécies de trabalhos remotos, necessariamente intermediados por recursos tecnológicos para sua realização e realizados preponderantemente fora das dependências da empresa.

É importante consignar que o serviço prestado no regime de teletrabalho como um todo, nisso incluindo o próprio home office, também pode ser executado nas dependências do empregador, todavia é realizado em outro local preponderantemente. No caso do home office em específico, no âmbito residencial do empregado.

Cita-se como exemplo o serviço prestado por um contador, na elaboração de contas, ou mesmo por um advogado, na elaboração de peças jurídicas e consultas. O serviço de ambos até pode ser desempenhado na sede dos seus respectivos escritórios, mas não há qualquer prejuízo de serem igualmente executados pela via remota.

Cumpre destacar que o teletrabalho, mormente o modelo home office, de modo geral, já era um regime conhecido, disciplinado por lei e difundido muito antes da pandemia da Covid-19.

Os tribunais trabalhistas, por exemplo, já enfrentaram diversas ações sobre o modelo ao longo dos últimos anos. No campo normativo, o teletrabalho foi disciplinado pela primeira vez em 2011, a partir da promulgação da Lei Federal de n. 12.551/2011, que alterou a Consolidação das Leis do Trabalho (CLT) em seu artigo $6^{\circ}$, incluindo essa modalidade:

Art. $6^{\circ}$ Não se distingue entre o trabalho realizado no estabelecimento do empregador, o executado no domicílio do empregado e o realizado a distância, desde que estejam caracterizados os pressupostos da relação de emprego.

Parágrafo único. Os meios telemáticos e informatizados de comando, controle e supervisão se equiparam, para fins de subordinação jurídica, aos meios pessoais e diretos de comando, controle e supervisão do trabalho alheio.

Na sequência, já no ano de 2017, com a popularização do modelo, o teletrabalho foi regulamentado de maneira mais detalhada com a promulgação da Lei de Reforma Trabalhista (Lei Federal n. 13.467/2017), que dedicou um capítulo sobre o assunto 
(capítulo II-A) a partir do artigo 75-A e seguintes, delimitando o conceito legal do teletrabalho, limites de sua aplicação e requisitos formais para sua implementação. O conceito legal do regime do teletrabalho, nisso incluído também o modelo home office, é delimitado no artigo 75-B da CLT, segundo o qual: “Considera-se teletrabalho a prestação de serviços preponderantemente fora das dependências do empregador, com a utilização de tecnologias de informação e de comunicação que, por sua natureza, não se constituam como trabalho externo".

Existem alguns requisitos formais estabelecidos na lei para implementação do regime de teletrabalho no âmbito das relações empregatícias:

1) que essa modalidade de regime, via teletrabalho, esteja expressamente prevista no contrato de trabalho individual do empregado, conforme previsto no artigo 75-C da CLT: “A prestação de serviços na modalidade de teletrabalho deverá constar expressamente do contrato individual de trabalho, que especificará as atividades que serão realizadas pelo empregado".

2) também com base nesse artigo, que seja consignado, no contrato individual ou aditivo, todo o rol de atividades que deverão ser realizadas pelo empregado nesse modelo;

3) que haja expressa concordância do empregado, no contrato individual ou em aditivo contratual, sobre a possibilidade de implementação do teletrabalho, havendo acordo mútuo entre trabalhador e empregador sobre a adoção desse regime conforme previsto no parágrafo $1^{\circ}$ do artigo 75-C da CLT: “Poderá ser realizada a alteração entre regime presencial e de teletrabalho desde que haja mútuo acordo entre as partes, registrado em aditivo contratual”.

4) previsão contratual sobre de quem será a responsabilidade de fornecer os equipamentos e recursos tecnológicos como computadores, notebooks, tablets, internet, cadeiras, mesas etc., se do trabalhador ou do empregador; no caso deste último, a lei estabelece que qualquer valor pago sob esse pretexto não será reputado como remuneração do empregado (artigo 75-D da CLT):

Art. 75-D. As disposições relativas à responsabilidade pela aquisição, manutenção ou fornecimento dos equipamentos tecnológicos e da infraestrutura necessária e adequada à prestação do trabalho remoto, bem como ao reembolso de despesas arcadas pelo empregado, serão previstas em contrato escrito. 
5) que haja, por parte do empregador, instrução do empregado quanto aos cuidados e às precauções necessários a serem adotadas para evitar doenças e acidentes de trabalho, assinando, na sequência, o empregado termo de responsabilidade se comprometendo a seguir todas as instruções fornecidas (artigo 75-E e parágrafo único da CLT):

Art. 75-E. O empregador deverá instruir os empregados, de maneira expressa e ostensiva, quanto às precauções a tomar a fim de evitar doenças e acidentes de trabalho.

Parágrafo único. O empregado deverá assinar termo de responsabilidade comprometendo-se a seguir as instruções fornecidas pelo empregador.

Além desses necessários requisitos formais, o teletrabalho também apresenta algumas peculiaridades estabelecidas em lei. Por exemplo, para que o regime de teletrabalho seja adotado, conforme visto, é necessário um acordo mútuo quanto ao modelo entre empregado e empregador, formalizado contratualmente (artigo 75-C, parágrafo $1^{\circ}$ ): “Poderá ser realizada a alteração entre regime presencial e de teletrabalho desde que haja mútuo acordo entre as partes, registrado em aditivo contratual”.

Nada impede, contudo, que o inverso ocorra, isto é, que o empregado saia do regime telepresencial para o presencial. Nesse caso, contudo, não há necessidade de concordância do empregado a respeito, sendo de livre deliberação do empregador, havendo apenas a condição de que este informe ao trabalhador sobre a mudança do modelo para o presencial com uma antecedência mínima 15 dias com o intuito de viabilizar a transição de um regime para o outro (artigo 75-C, parágrafo $2^{\circ}$ ): "Poderá ser realizada a alteração do regime de teletrabalho para o presencial por determinação do empregador, garantido prazo de transição mínimo de quinze dias, com correspondente registro em aditivo contratual".

Outra peculiaridade do modelo é que o teletrabalho foi incluído no artigo 62 da CLT, que lista os casos em que o trabalhador não fica sujeito a controle de jornada, não fazendo jus, por exemplo, a horas extras e adicional noturno. Todavia, cumpre destacar que, em se verificando que o empregador se utiliza de ferramentas remotas que viabilizem esse controle de jornada, como verificação de acessos a sistemas, o caso sai da exceção do artigo 62 da CLT, sendo possível a condenação em eventuais horas extras laboradas pelo empregado, conforme aponta Martins (2021, p. 803): 
Não são abrangidos pelo capítulo da duração de trabalho os empregados em regime de teletrabalho (art. 62, III, da CLT). Não fazem jus, portanto, a horas extras. O dispositivo tem de ser interpretado sistematicamente ou em conjunto com o parágrafo único do art. $6^{\circ}$ da CLT. Este dispositivo faz referência ao comando, controle e supervisão por meios telemáticos e informatizados em relação ao teletrabalho. Se houver controle de entrada e saída de dados no computador do empregado, o trabalhador terá direito a horas extras.

Outra peculiaridade do modelo é que nada impede que, no curso do regime de teletrabalho, o empregado seja demandado a comparecer presencialmente às dependências do empregador para laborar. Isso, por si só, não descaracteriza esse modelo, conforme previsto no artigo 75-B, parágrafo único da CLT: "O comparecimento às dependências do empregador para a realização de atividades específicas que exijam a presença do empregado no estabelecimento não descaracteriza o regime de teletrabalho".

É importante, todavia, que as atividades do trabalhador sejam prestadas preponderantemente de maneira remota (no caso específico do home office, no âmbito residencial do empregado) sob pena de invalidação do regime e, por exemplo, obrigação legal do empregador em controlar a jornada do empregado e, a depender do caso, pagar horas extras eventualmente realizadas pelo trabalhador. Assim, é de se ver que o home office, no contexto do teletrabalho, já vinha sendo bastante difundido no país, já apresentando disciplina própria legal, com estabelecimentos de critérios, regras e requisitos para sua implementação.

É no momento da pandemia, no entanto, que o modelo se amplia exponencialmente como uma alternativa no país, mormente o regime home office, por se desenrolar preponderantemente no ambiente residencial do empregado, tornando possível o cumprimento da medida do distanciamento social.

O modelo sofreu no período pandêmico uma série de modificações legislativas, seja por inciativa do governo federal, seja por inciativa do Congresso Nacional, para desburocratizar e viabilizar a migração dos contratos ativos presenciais para o modelo remoto o mais depressa possível, justamente por conta do cumprimento da necessária medida do distanciamento social. Essas mudanças legislativas, ocorridas até mesmo por meio de medidas provisórias, serão objeto de estudo da unidade seguinte. 


\section{Adoção do home office como ferramenta do distanciamento social}

Conforme mencionado anteriormente, enquanto a vacina não era disponibilizada e, hodiernamente, enquanto significativa parte da população, mormente no Brasil, não era vacinada, a OMS recomendou uma série de medidas para enfrentamento da doença envolvendo comportamento social, em especial o distanciamento social.

No Brasil, apesar do posicionamento contrário à medida mormente pela liderança do governo, as autoridades de saúde também recomendaram a adoção da medida, popularizada na internet com hashtags a exemplo do "\#ficaemcasa".

Àqueles segmentos que desenvolvem atividades que não precisam ser realizadas presencialmente, em especial as de natureza intelectual, no contexto das relações do trabalho, a opção pelo uso do modelo home office foi feito de maneira praticamente automática.

É interessante pontuar o efeito da globalização em seus aspectos negativos e positivos pois, se por um lado, é o que potencializou a disseminação da doença pela facilidade de transporte de pessoas entre países, cidades, por vias terrestres, aéreas e marítimas, ampliando as possibilidades de disseminação do vírus, por outro, dentro do seu modelo, marcado principalmente pela interconexão global por meio da rede mundial de computadores associada à internet, ofereceu alternativas para a não estagnação total das atividades no país.

No segmento da educação, por exemplo, pelo modelo de ensino a distância (EaD), foi possível, para muitos estudantes, prosseguir o ano letivo acessando as aulas pela via remota em razão do fechamento das escolas, não obstante aqui se ressalve que, infelizmente, sobretudo na rede pública de ensino, a inclusão digital ainda seja um problema para parte significativa da população.

No segmento da saúde, por sua vez, as plataformas digitais também ampliaram o modelo das consultas médicas pela via remota. Berlinguer (1999, p. 29) pontua muito bem essa questão ao correlacionar a globalização com as chamadas doenças globais:

[...] o reaparecimento de velhas infecções e o surgimento de novas deve nos induzir a não esquecer que insetos, vírus, micróbios e parasitas viajam sem passaporte e passam sem visto pelas fronteiras. "Desde que o mundo se tornou menor, graças aos atuais meios de comunicação (...) a solidariedade humana no campo da saúde não pode ficar impunemente descuidada”, como escreveu Henry Sigerist em Civilization and disease, no ano de 1943, ou seja, há 56 anos. 
No comércio, a virtualização das lojas de venda de bens e serviços intensificou as atividades on-line, prosseguindo com o negócio via plataformas digitais, como Instagram, Facebook, WhatsApp, sites de compras coletivas, entre outras.

É certo que, sob uma perspectiva pós-modernista, em que se refuta a ideia de que a ciência e mesmo o avançar da tecnologia trarão a almejada "felicidade" ao homem, apresentando reposta a todos problemas sociais, refletindo sobre os pesares que ela também pode ocasionar, como abusos online, precarização das relações de trabalho, crimes cibernéticos, quebra da privacidade, é preciso estabelecer o contraponto e "dar a César o que é de César”.

Há que se fazer justiça ao quanto a tecnologia pode trazer de benefício ao social, cumprindo, principalmente na pandemia, o papel importantíssimo de viabilizar uma alternativa do prosseguimento das atividades pela via remota, evitando assim a estagnação das atividades comerciais, a falência de diversas empresas, a perda de muitos postos de trabalho e a estagnação econômica do país. Tudo isso, repise-se, permitindo o cumprimento da medida do distanciamento social.

A ampliação do uso do home office foi um dos exemplos mais populares de implementação tecnológica que viabilizaram o cumprimento dessa importante medida.

É de se destacar que nem para todos os setores a sua implementação foi possível. As atividades necessariamente presenciais, como entregadores, motoristas, atendentes de supermercados, farmácias, padarias, trabalhadores de obras etc., não se beneficiaram do modelo, por incompatibilidade com a execução dos serviços de natureza essencialmente presencial.

É impossível, por exemplo, para um pedreiro exercer o seu ofício de maneira diversa da presencial, do mesmo modo que um motorista de ônibus coletivo execute essa atividade de um home office. Repise-se, são atividades de natureza essencialmente presenciais. Não se pode ignorar, contudo, a ampliação do uso do modelo impulsionado pela pandemia da Covid-19, quanto aos segmentos que apresentaram compatibilidade com o dito regime, sobretudo quanto àqueles que desenvolvem atividades de natureza intelectual.

Uma pesquisa realizada e divulgada pelo Instituto de Pesquisa Econômica Aplicada Ipea (2020) demonstrou que, entre as principais ocupações passíveis do uso do modelo telepresencial, no período da pandemia, foram: diretores e gerentes com 61\%, profissionais das ciências e intelectuais com $65 \%$, técnicos e profissionais com nível médio com $30 \%$, empregados de apoio administrativo com $41 \%$, vendedores em comércios e mercados com $12 \%$. 
Já o Instituto Brasileiro de Geografia e Estatística (IBGE) divulgou uma pesquisa importante no curso da pandemia, na qual apontava que, em maio de 2020, 8,5 milhões de pessoas estavam trabalhando remotamente.

Para viabilizar a migração dos contratos presenciais, mormente na iniciativa privada, para os modelos remotos, principalmente para o regime home office, no período da pandemia, publicou-se, no Brasil, uma série de medidas normativas de inciativa do governo federal e do Congresso no sentido de desburocratizar e incentivar a transição do trabalho presencial para o trabalho remoto, com segurança jurídica para empregador e trabalhador, conforme será mais bem detalhado a seguir.

\subsection{Das leis implementadas no curso da pandemia}

A primeira alteração legislativa ocorrida no curso da pandemia e que envolveu, entre outros dispositivos para enfrentamento da crise decorrente da disseminação da Covid-19, alteração das regras do contrato de teletrabalho, foi a Medida Provisória (MP) n. 927/2020, editada em 22 de março de 2020. A MP em questão incluiu o teletrabalho expressamente como uma medida para enfrentamento dos efeitos econômicos decorrentes do estado de calamidade pública e para preservação do emprego e da renda, em seu artigo $3^{\circ}$, item I:

Art. $3^{\circ}$ Para enfrentamento dos efeitos econômicos decorrentes do estado de calamidade pública e para preservação do emprego e da renda, poderão ser adotadas pelos empregadores, dentre outras, as seguintes medidas:

I- O teletrabalho; [...].

Além disso, a MP n. 927/2020 reservou um capítulo todo para disciplinar o teletrabalho no período da pandemia (capítulo II), a partir do seu artigo $4^{\circ}$ e seguintes, em especial dispensando a exigência da formalização prévia por contrato individual ou mesmo acordos coletivos para alteração dos contratos de trabalho do modelo presencial para o remoto.

A perda da vigência da MP n. 927/2020 ocorreu em 19 de julho de 2020, de modo que, após esse ínterim, os contratos no modelo teletrabalho, para terem validade, voltaram a observar os requisitos formais previstos na CLT (isso até entrar em vigor, já no ano seguinte, a MP n. 1.046/2021 que será à frente mais bem abordada). Não obstante, 
durante a vigência da MP n. 927/2020, os acordos feitos no seu curso continuaram válidos.

Entre as principais mudanças que se podem suscitar quanto às implementadas pela MP n. 927/2020, tem-se o artigo $4^{\circ}$, no qual restou estabelecido que, no curso da pandemia, o empregador poderia alterar o regime de trabalho presencial para o teletrabalho e todas as suas espécies, independentemente da existência de acordos individuais ou coletivos, dispensando, inclusive, a formalização contratual prévia que apontava a possibilidade da mudança entre os regimes:

Art. $4^{\circ}$ Durante o estado de calamidade pública a que se refere o art. $1^{\circ}$, o empregador poderá, a seu critério, alterar o regime de trabalho presencial para o teletrabalho, o trabalho remoto ou outro tipo de trabalho a distância e determinar o retorno ao regime de trabalho presencial, independentemente da existência de acordos individuais ou coletivos, dispensado o registro prévio da alteração no contrato individual de trabalho.

A MP n. 927/2020, ao seu turno, estabeleceu que o prazo para notificação, pelo empregador ao empregado, informando sobre a mudança do regime presencial para o remoto era de apenas 48 horas, por escrito ou por meio eletrônico (artigo $4^{\circ}$, parágrafo $2^{\circ}$ ): “A alteração de que trata o caput será notificada ao empregado com antecedência de, no mínimo, quarenta e oito horas, por escrito ou por meio eletrônico”.

Estabeleceu também prazo diverso para a formalização contratual no que tange à responsabilidade quanto às despesas com a aquisição, a manutenção ou o fornecimento dos equipamentos tecnológicos e da infraestrutura necessária e adequada à prestação do teletrabalho, trabalho remoto ou trabalho a distância, que, não obstante, tivessem a necessidade ainda de ser formalizados por escrito. Essa formalização poderia ocorrer tanto antes da migração do trabalhador ao regime remoto ou, alternativamente, no prazo de 30 dias contado da data da mudança do regime de trabalho (artigo $4^{\circ}$, parágrafo $\left.3^{\circ}\right)$ :

$\$ 3^{\circ}$ As disposições relativas à responsabilidade pela aquisição, pela manutenção ou pelo fornecimento dos equipamentos tecnológicos e da infraestrutura necessária e adequada à prestação do teletrabalho, trabalho remoto ou trabalho a distância e ao reembolso de despesas arcadas pelo empregado serão previstas em contrato escrito, firmado previamente ou no prazo de trinta dias, contado da data da mudança do regime de trabalho. 
Estendeu também a possibilidade de instituição do regime teletrabalho a estagiários e aprendizes (artigo $4^{\circ}$, parágrafo $5^{\circ}$ ): "Fica permitida a adoção do regime de teletrabalho, trabalho remoto ou trabalho a distância para estagiários e aprendizes, nos termos do disposto neste Capítulo”.

Ato contínuo, o governo também publicou a MP n. 936/2020 em $1^{\circ}$ de abril de 2020. A MP n. 936/2020 não chegou a abordar com riqueza de detalhes a questão do teletrabalho em si. Todavia, o instituto é mencionado no seu artigo $8^{\circ}$, parágrafo $4^{\circ}$, estabelecendo que, se o trabalhador sujeito à suspenção do contrato na forma prevista na dita MP permanecesse atuando em favor do empregador por meio do teletrabalho, trabalho remoto ou trabalho a distância, a suspensão do contrato temporário restaria descaracterizada, recaindo sobre o empregador uma série encargos remuneratórios em favor do empregado:

$\$ 4^{\circ}$ Se durante o período de suspensão temporária do contrato de trabalho o empregado mantiver as atividades de trabalho, ainda que parcialmente, por meio de teletrabalho, trabalho remoto ou trabalho à distância, ficará descaracterizada a suspensão temporária do contrato de trabalho, e o empregador estará sujeito:

I - ao pagamento imediato da remuneração e dos encargos sociais referentes a todo o período;

II - às penalidades previstas na legislação em vigor; e

III - às sanções previstas em convenção ou em acordo coletivo.

A MPn. 936/2020 foi convolada em lei (Lei Federal n. 14.020/2020) em 7 de julho de 2020. Subsequentemente, o governo ainda editou a MP n. 1.046/2021. Esta, ao menos no que tange ao teletrabalho, reproduziu a mesma linha de flexibilização das regras para migração do regime presencial para o teletrabalho visto que a MP n. 927/2020 já tinha perdido vigência, dedicando, igualmente, um capítulo para tratar sobre o regime praticamente com o mesmo teor da MP n. 927/2020 a partir do artigo $3^{\circ} \mathrm{e}$ seguintes.

Além das modificações implementadas pelas medidas provisórias e pela lei, que alteram alguns requisitos formais previstos na CLT para o teletrabalho, incluindo neste o home office, é importante destacar a Nota Técnica n. 17/2020 emitida pelo Ministério Público do Trabalho que também trouxe importantes recomendações a empregados e empregadores que adotaram o regime do teletrabalho. 
Entre elas, cita-se a recomendação da cláusula $2^{\mathrm{a}}$ no sentido de formalizar o contrato regulamentando a transição do modelo presencial para o remoto mesmo no curso da pandemia:

2. REGULAR a prestação de serviços em regime de teletrabalho, mesmo no período de medidas de contenção da pandemia da COVID-19, por meio de contrato de trabalho aditivo por escrito, tratando de forma específica sobre a duração do contrato, a responsabilidade e a infraestrutura para o trabalho remoto, bem como o reembolso de despesas relacionadas ao trabalho realizadas pelo empregado, nos termos da legislação trabalhista, da legislação aplicável à administração pública e das limitações, procedimentos e determinações dos Órgãos de Controle [...].

Cita-se, ao seu turno, a recomendação da cláusula $3^{\mathrm{a}}$ quanto à necessária observância, pelas empresas, de manter os parâmetros de ergonomia e organização do trabalho no modelo do teletrabalho, observando a adequação do mobiliário utilizado, treinamentos de posturas, reembolsando despesas necessárias ao funcionamento do trabalho pela via remota etc. Observe-se:

3. OBSERVAR os parâmetros da ergonomia, seja quanto às condições físicas ou cognitivas de trabalho (por exemplo, mobiliário e equipamentos de trabalho, postura física, conexão à rede, design das plataformas de trabalho online), quanto à organização do trabalho (o conteúdo das tarefas, as exigências de tempo, ritmo da atividade), e quanto às relações interpessoais no ambiente de trabalho (formatação das reuniões, transmissão das tarefas a ser executadas, feedback dos trabalhos executados), oferecendo ou reembolsando os bens necessários ao atendimento dos referidos parâmetros, nos termos da lei, bem como limitações, procedimentos e determinações dos Órgãos de Controle, tais como Tribunais de Contas no caso da Administração Pública.

Ao seu turno, a cláusula $6^{\mathrm{a}}$ traz recomendação sobre a orientação do empregado no novo regime, no sentido de evitar que acidentes do trabalho ocorram: "INSTRUIR os empregados, de maneira expressa, clara e objetiva, quanto às precauções a tomar a fim de evitar doenças, físicas e mentais e acidentes de trabalho, bem como adotar medidas de segurança como intervalos e exercícios laborais”.

Menciona-se ainda a recomendação da cláusula $7^{\text {a }}$ que diz respeito à necessária observação da jornada contratual estabelecida, compatibilizando necessidades empresariais e dos trabalhadores em seu âmbito familiar: 
7. OBSERVAR a jornada contratual na adequação das atividades na modalidade de teletrabalho e em plataformas virtuais, com a compatibilização das necessidades empresariais e das trabalhadoras e trabalhadores responsabilidades familiares (pessoas dependentes sob seus cuidados) na elaboração das escalas laborais que acomodem as necessidades da vida familiar, especialmente nutrizes, incluindo flexibilidade especial para trocas de horário e utilização das pausas (NR 17, Anexo II, 5.1.2.1).

Todas essas medidas, de modo geral, somadas à necessidade de se manter o distanciamento social no curso da pandemia, explicam a ampliação do regime de teletrabalho, mormente no modelo home office, pelo país no curso da pandemia, e demonstram o sucesso e viabilidade do seu uso sustentável.

Os recursos tecnológicos que tornaram o modelo do home office possível, no curso da pandemia, sem dúvida alcançaram status de ferramenta efetiva de combate à disseminação do vírus, trazendo mais segurança à saúde do trabalhador e da população, de modo geral. Nesse particular, viva a tecnologia!

\section{Conclusão}

O presente artigo se propôs a examinar o fenômeno da ampliação do home office no Brasil, no curso da pandemia decorrente da disseminação da Covid-19 pelo país. Foi contextualizado que esse modelo de trabalho é um fruto típico da sociedade da informação hodiernamente vivida, caracterizada pela implementação da tecnologia e interconexão via internet de uma rede mundial de computadores com alcance global, marcada também pela geração e reprodução aplicada de dados que, transmitidos em tempo instantâneo, tornam relativa até mesmo a noção estática do tempo e espaço.

Conforme examinado, o home office é uma espécie do gênero teletrabalho, que já é um regime que tem apresentado regulamentação desde 2011. Pontuou-se que a regulamentação estabelecida para o teletrabalho, de maneira geral, também disciplina a sua espécie home office.

Foi examinado ainda que, com a chegada da Lei de Reforma Trabalhista (Lei Federal n. 13.467/2017), o teletrabalho ganhou um capítulo próprio na CLT, dispondo sobre sua conceituação, seus elementos e necessários requisitos formais a serem preenchidos para sua implementação. 
A pesquisa verificou que o teletrabalho pode se desenvolver de várias formas como nos modelos centros satélites, telecentros, telecottages, nômade ou móvel, sendo o home office apenas um deles. De modo geral, o teletrabalho, nisso incluído o home office, é aquele exercido preponderantemente fora das dependências da empresa, de maneira remota, por meio do uso de recursos tecnológicos como internet e computador.

Dentro do teletrabalho, o home office, como uma de suas espécies, diferencia-se por se desenvolver preponderantemente dentro do ambiente residencial do empregado. Essa particularidade foi de grande valia no urso da pandemia da Covid-19, notadamente porque o distanciamento social é uma das medidas mais importantes e recomendadas pela OMS no combate à disseminação do vírus.

Isso explica o motivo pelo qual o modelo se ampliou tanto no Brasil, a ponto de pesquisas apontarem que, somente até maio de 2020, a quantidade de pessoas que estavam trabalhando remotamente foi de 8,5 milhões, mormente em regime de home office.

O estudo também examinou importantes modificações legislativas que ocorreram no curso da pandemia, mormente para desburocratizar e tornar mais rápida a migração dos contratos de trabalho em curso, sobretudo na iniciativa privada, que estavam no modelo presencial para o telepresencial, em especial no regime home office. É o caso das MPs n. 927/2020 e 936/2020, esta última convertida na Lei Federal n. 14.020/2020, e, por fim, a MP no 1.046/2021.

O estudo conclui que a tecnologia tem sido uma importante aliada para a não paralisação das atividades comerciais em função da pandemia, mormente pelo uso do home office, que permite a continuidade da prestação de serviços respeitando o distanciamento social, tão recomendado como medida de combate à disseminação do vírus.

Nesse contexto, os recursos tecnológicos que tornaram o modelo do home office possível, no curso da pandemia, sem dúvida alcançaram status de ferramenta efetiva de combate à disseminação do vírus, trazendo mais segurança à saúde do trabalhador e da população de modo geral. É de se ver, portanto, que o home office, antes encarado apenas como uma alternativa, hoje se consolida como um modelo de trabalho eficaz, mormente no contexto da pandemia, como ferramenta de proteção à saúde da população em geral. 


\section{REFERÊNCIAS}

BARRETOJUNIOR, I. F. Atualidade do conceito sociedade da informação para a pesquisa jurídica. In: PAESANI, L. M (coord.). O direito na sociedade da informação. São Paulo: Atlas, 2007.

BARRETO JUNIOR, I. F.; SILVA, J. M. da. Teletrabalho e sociedade da informação: modalidades e jornada de trabalho. Revista de Direitos e Garantias Fundamentais, v. 16, n. 2, p. 29-56, 2015. DOI: https:// doi.org/10.18759/rdgf.v16i2.467. Disponível em: https://sisbib.emnuvens.com.br/direitosegarantias/article/view/467. Acesso em: $22 \mathrm{dez} .2021$.

BERLINGUER, G. (1999). Globalização e saúde global. Estudos Avançados, v. 13, n. 35, p. 21-38, 1999. Disponível em: https://www.revistas.usp.br/eav/article/view/9454/11022. Acesso em: 22 dez. 2021.

BRASIL. [Constituição (1988)]. Constituição da República Federativa do Brasil de 1988. Brasília, DF: Presidência da República. Disponível em: http://www.planalto.gov.br/ccivil_03/constituicao/constituicao.htm. Acesso em: 20 jun. 2021.

BRASIL. Decreto-Lei $n^{\circ}$ 5.452, de $1^{\circ}$ de maio de 1943. Aprova a Consolidação das Leis de Trabalho. Brasília, DF: Presidência da República. Disponível em:http://www.planalto.gov.br/ccivil_03/decreto-lei/ del5452.htm. Acesso em: 20 jun. 2021.

BRASIL. Lei no 14.020, de 6 de julho de 2020. Institui o Programa Emergencial de Manutenção do Emprego e da Renda; dispõe sobre medidas complementares para enfrentamento do estado de calamidade pública reconhecido pelo Decreto Legislativo $n^{\circ}$ 6, de 20 de março de 2020, e da emergência de saúde pública de importância internacional decorrente do coronavírus, de que trata a Lei ${ }^{\circ} 13.979$, de 6 de fevereiro de 2020; altera as Leis n os 8.213, de 24 de julho de 1991, 10.101, de 19 de dezembro de $2000,12.546$, de 14 de dezembro de 2011, 10.865, de 30 de abril de 2004, e 8.177, de $1^{\circ}$ de março de 1991; e dá outras providências. Brasília, DF: Presidência da República, 2020. Disponível em: http:// www.planalto.gov.br/ccivil_03/_ato2019-2022/2020/lei/L14020.htm. Acesso em: 20 jun. 2021.

BRASIL. Medida Provisória no 927, de 22 de março de 2020. Dispõe sobre as medidas trabalhistas para enfrentamento do estado de calamidade pública reconhecido pelo Decreto Legislativo $n^{\circ} 6$, de 20 de março de 2020, e da emergência de saúde pública de importância internacional decorrente do coronavírus (covid-19), e dá outras providências. Brasília, DF: Presidência da República, 2020. Disponível em: http://www.planalto.gov.br/ccivil_03/_ato2019-2022/2020/mpv/mpv927.htm. Acesso em: 20 jun. 2021.

BRASIL. Medida Provisória no 936, de $1^{\circ}$ de abril de 2020. Institui o Programa Emergencial de Manutenção do Emprego e da Renda e dispõe sobre medidas trabalhistas complementares para enfrentamento do estado de calamidade pública reconhecido pelo Decreto Legislativo $n^{\circ} 6$, de 20 de março de 2020, e da emergência de saúde pública de importância internacional decorrente do coronavírus (covid-19), de que trata a Lei no 13.979, de 6 de fevereiro de 2020, e dá outras providências. Brasília, DF: Presidência da República, 2020. Disponível em: http://www.planalto.gov.br/ccivil_03/_ato20192022/2020/mpv/mpv936.htm. Acesso em: 20 jun. 2021.

BRASIL. Medida Provisória no 1.046, de 27 de abril de 2021. Dispõe sobre as medidas trabalhistas para enfrentamento da emergência de saúde pública de importância internacional decorrente do coronavírus (covid-19). Brasília, DF: Presidência da República, 2021. Disponível em: https://www.in.gov.br/en/ web/dou/-/medida-provisoria-n-1.046-de-27-de-abril-de-2021-316265470. Acesso em: 20 jun. 2021. 
BRASIL atinge marca trágica de 500 mil mortes pela Covid. G1, 19 jun. 2021. Disponível em: https:// g1.globo.com/jornal-nacional/noticia/2021/06/19/brasil-atinge-marca-tragica-de-500-mil-mortes-pela-covid.ghtml. Acesso em: 20 jun. 2021.

INSTITUTO DEPESQUISA ECONÔMICA APLICADA. Carta de Conjuntura número 47. Ipea, $2^{\circ}$ trim. 2020. Disponível em: https://www.ipea.gov.br/portal/images/stories/PDFs/conjuntura/200608_nt_ cc47_teletrabalho.PDF. Acesso em: 20 jun. 2021.

LISBOA, R. S. Direito da sociedade da informação: a contribuição japonesa. In: LISBOA, R. S. (coord.). $\mathrm{O}$ direito na sociedade da informação $I V$ : movimentos sociais, tecnologia e a atuação do Estado. São Paulo: Almedina, 2020.

MARTINS, S. P. Direito do trabalho. 37. ed. São Paulo: Saraiva Educação, 2021.

MINISTÉRIO PÚBLICO DO TRABALHO. Nota Técnica 17/2020 do GT Nacional Covid-19 e do GT Nanotecnologia/2020. Disponível em: https://mpt.mp.br/pgt/noticias/nota-tecnica-n-17-sobre-trabalho-remoto-gt-covid-19-e-gt-nanotecnologia-1.pdf?fbclid=IwAR0qIu5h61T9U4VH-7IxcDmDfNEbXcUATURtUYamM_p7WLnzE0aaHw9q4Uc. Acesso em: 20 jun. 2021.

OMS esclarece que assintomáticos transmitem coronavírus: “a questão é saber quanto”. G1, 9 jun. 2020. Disponível em: https://g1.globo.com/bemestar/coronavirus/noticia/2020/06/09/transmissao-por-casos-assintomaticos-esta-ocorrendo-a-questao-e-saber-quanto-diz-oms.ghtml. Acesso em: 20 jun. 2021.

RODRIGUES, A. C. B. Teletrabalho: a tecnologia transformando as relações de trabalho. 2011. Dissertação (Mestrado em Direito do Trabalho e da Seguridade Social) - Universidade de São Paulo, São Paulo, 2011. Disponível em: https://www.teses.usp.br/teses/disponiveis/2/2138/tde-14062012-112439/ publico/TELETRABALHO_A_tecnologia_transformando_as_relacoes_de_trabalho_Integral.pdf. Acesso em: 22 dez. 2021.

TRIBUNAL SUPERIOR DO TRABALHO. Teletrabalho: o trabalho de onde você estiver. Brasília: TST, 2020. Disponível em: e5486dfc-d39e-a7ea-5995-213e79e15947 (tst.jus.br). Acesso em: 20 jun. 2021. 